\section{PERNIKAHAN DINI DI MASA PANDEMI \\ COVID-19}

ILMIA LARASHATI

IIK STRADA Indonesia

Email (ilmiagurah@gmail.com)

\section{ABSTRAK}

Wabah Pandemi COVID-19 terjadi hampir di seluruh dunia, termasuk Indonesia. Kondisi ini menimbulkan kekhawatiran terhadap kesehatan dan keselamatan bagi masyarakat luas. Di Indonesia, berbagai kebijakan dan upaya telah dilakukan oleh pemerintah daerah maupun pusat dalam menanggulangi penyebaran virus COVID-19. Saat ini, pemerintah telah menerapkan Pemberlakuan Pembatasan Kegiatan Masyarakat (PPKM) level 4 pada beberapa kota maupun kabupaten tertentu. Hal menarik untuk menjadi kajian dan perhatian bersama saat pandemi COVID19 adalah fenomena pernikahan dini di masa pandemi COVID-19. Metode penelitian ini menggunakan penelitian kualitatif. Penelitian ini dilakukan di Kabupaten Madiun. Teknik pengumpulan data dalam penelitian ini dihimpun melalui observasi, wawancara mendalam, dan dokumentasi. Peneliti mengambil responden yang akan diwawancarai sebagai informan dengan ketentuan bersedia untuk diwawancarai. Teknik keabsahan data menggunakan triangulasi teknik. Teknik analisis data yang digunakan dalam penelitian ini menggunakan model analisis interaktif
Miles-Huberman. Hasil penelitian menunjukkan bahwa jumlah pernikahan dini selama masa pandemi COVID-19 mengalami kenaikan hingga mencapai 175 orang/pasangan sepanjang tahun 2020. Fenomena pernikahan dini yang terjadi selama masa pandemi COVID-19 disebabkan karena married by accident. Hubungan seksual ini rentan terjadi diantara mereka yang telah meningkat remaja menuju dewasa. Bentuk perilaku seksual ini, umumnya diawali saat mereka (pasangan) mulai pacaran

Kata kunci : Pernikahan Dini, Pandemi Covid $-19$

\section{PENDAHULUAN}

Wabah Pandemi COVID-19 terjadi hampir di seluruh dunia, termasuk Indonesia. World Health Organization(WHO) telah menyatakan bahwa penyebaran COVID-19 sebagai kondisi pandemi global (Watkins, 2020; Cucinotta \& Vanelli, 2020; Sohrabi et al., 2020; Mahase, 2020; Wahyono dkk, 2020). Kondisi ini menimbulkan kekhawatiran terhadap kesehatan dan keselamatan bagi masyarakat luas. Di Indonesia, berbagai kebijakan dan upaya telah dilakukan oleh pemerintah daerah maupun pusat dalam menanggulangi penyebaran virus COVID-19. Saat ini, pemerintah telah menerapkan Pemberlakuan Pembatasan Kegiatan Masyarakat (PPKM) level 4 pada beberapa kota maupun kabupaten tertentu. Hal menarik untuk menjadi kajian dan perhatian bersama saat pandemi COVID-19 adalah meningkatnya jumlah pernikahan dini.Permasalahan 
pernikahan dini telah banyak terjadi hampir di pedesaan maupun perkotaan. Pernikahan dini merupakan suatu pernikahan yang dilakukan oleh seseorang yang usianya masih relatif muda. Mengutip dalam Undang-Undang RI Nomor 1 Tahun 1974 tentang Perkawinan, yang tertuang dalam pasal 7 ayat 1 telah dinyatakan bahwa perkawinan diizinkan jika pihak calon mempelai pria sudah mencapai umur 19 (sembilan belas) tahun dan calon mempelai wanita sudah mencapai umur 16 (enam belas) tahun. Perubahan atas Undang-Undang tersebut telah dituangkan dalam Undang-Undang RI Nomor 16 Tahun 2019. Ketentuan batas usia ideal untuk menikah dinyatakan dalam dalam pasal 7 , yang menegaskan bahwa perkawinan hanya diijinkan apabila pihak pria dan wanita sudah mencapai usia 19 (sembilan belas) tahun. Fenomena pernikahan dini selama masa pandemi COVID-19 yang terjadi di Kabupaten Madiun naik secara signifikan. Kenaikannya lebih dari $100 \%$ dibandingkan kasus pernikahan dini pada tahun sebelumnya. Zainal Arifin, Ketua Pengadilan Agama Kabupaten Madiun, menyatakan bahwa kasus pernikahan dini selama masa pandemi COVID-19 di sepanjang tahun 2020 mengalami kenaikan $100 \%$ apabila dibandingkan dengan tahun sebelumnya. Selama tahun 2019, jumlah pengajuan dispensasi kawin hanya 50orang, dan memasuki bulan Agustus tahun 2020 mencapai 120 pengajuan (www.madiunpos.com). Berdasarkan penelitian yang dilakukan oleh Apriliani \& Nurwati (2020), tentang pengaruh perkawinan muda terhadap ketahanan keluarga. Hasil penelitian menyatakan bahwa perkawinan usia muda rentan terjadi perceraian akibat kondisi psikologis pasangan yang belum stabil. Hal lain adalah memberikan dampak pada ketahanan keluarga yang dibangun. Melihat kondisi di lapangan yang terjadi, bahwa perkawinan terjadi bukan atas dasar ketentuan ketahanan keluarga, hanya pada kesiapan secara fisik saja. Hal ini akan mempengaruhi pada kondisi psikologisnya, tingkat emosi yang masih labil dapat menyebabkan ketahanan keluarga menjadi rapuh. Hasil penelitian Oktavia, dkk. (2018), tentang pengetahuan resiko pernikahan dini pada remaja umur 13-19 tahun. Hasil penelitian ini mengungkapkan bahwa tingkat pengetahuan remaja usia 13-19 tahun mayoritas tergolong berpengetahuan cukup dengan prosentase $78 \%$, yang dipengaruhi oleh rendahnya pendidikan remaja dan pemahaman dari remaja yang minim. Fenomena pandemi COVID-19 membuat peneliti tertarik untuk melakukan penelitian mengenai eksistensiatau fenomenapernikahan dini. Tujuan penelitian ini adalah untuk mengetahui fenomena pernikahan dini di masa pandemi covid di kabupaten Madiun.

\section{METODE}

Metode penelitian ini menggunakan penelitian kualitatif. Moleong (2011), mengartikan penelitian kualitatif adalah penelitian yang dialami responden pada suatu konteks khusus yang alamiah dengan memanfaatkan berbagai metode alamiah. Penelitian ini dilakukan di Kabupaten Madiun. Teknik pengumpulan data dalam penelitian ini dihimpun melalui observasi, wawancara mendalam, 
dan dokumentasi. Peneliti mengambil responden yang akan diwawancarai sebagai informan dengan ketentuan bersedia untuk diwawancarai. Teknik keabsahan data menggunakan triangulasi teknik, yaitu peneliti menggunakan teknik pengumpulan data yang berbeda-beda untuk mendapatkan data dari sumber yang sama (Sugiyono, 2019). Teknik analisis data yang digunakan dalam penelitian ini menggunakan model analisis interaktif Miles-Huberman (Moleong, 2011).HASIL Gambaran karakteristik sampel dalam penelitian ini adalah remaja di rentang usia 14 sampai dengan 18 tahun, yang telah menikah di usia muda pada periode bulan Januari sampai bulan Desember 2020. Hasil penelitian yang dilakukan mengenai pernikahan dini di Kabupaten Madiun, akan disajikan dalam tabel dispensasi kawin berikut.

\begin{tabular}{|l|c|c|}
\hline No & Bulan & Jumlah \\
\hline 1 & Januari & 24 \\
\hline 2 & Februari & 10 \\
\hline 3 & Maret & 18 \\
\hline 4 & April & 5 \\
\hline 5 & Mei & 3 \\
\hline 6 & Juni & 29 \\
\hline 7 & Juli & 23 \\
\hline 8 & Agustus & 8 \\
\hline 9 & September & 18 \\
\hline 10 & Oktober & 12 \\
\hline 11 & November & 15 \\
\hline
\end{tabular}

\begin{tabular}{|l|c|c|}
\hline 12 & Desember & 10 \\
\hline
\end{tabular}

Sumber data : Pengadilan Agama

Kabupaten Madiun 2020

Mengacu pada hasil rekapitulasi pengajuan dispensasi kawin dari tabel diatas diperoleh sebanyak 175 perkara, yang semuanya rata-rata telah putus kabul. Sebaran pernikahan usia muda sepanjang tahun 2020 menunjukkan usia yang paling muda yakni 14 tahun terdapat 10 pasangan yang menikah di usia yang masih sangat belia; di usia 15 tahun terdapat 9 pasangan yang telah diputus kabul dan telah melangsungkan pernikahannya; usia 16 tahun sebanyak 24 pasangan yang telah mengajukan permohonan dispensasi kawin; usia 17 tahun sebanyak 57 pasangan yang telah melangsungkan pernikahan; dan pengajuan di usia 18 tahun mencapai 75 pasangan yang telah memutuskan untuk menikah.

Mencermati sebaran usia diatas, nampak bahwa pernikahan yang telah terjadi masih belum sesuai harapan yang telah tertuang dalam perubahan atas UndangUndang RI Nomor 16 Tahun 2019. Kebijakan pemerintah dalam menetapkan ketentuan batas minimal usia ideal menikah tentunya melalui proses dan pertimbangan-pertimbangan. Hal tersebut dilakukan agar benar-benar siap secara lahirdan batin dalam memutuskan untuk menikah. Perkawinan yang dilakukan di usia yang masih muda mengandung sejumlah resiko dan cenderung berdampak negatif baik dari aspek psikologis/mental, sosial dan ekonomi, pendidikan, kesehatan reproduksi, ketahanan dalam keluarga yang masih labil 
dan rentan terhadap perceraian.

\section{PEMBAHASAN}

Hasil penelitian menunjukkan bahwa fenomena pernikahan dini yang terjadi di wilayah Kabupaten Madiun, dimana usia belum mencapai 19 tahun, seperti yang telah ditetapkan dalam perubahan atas Undang-Undang RI Nomor 16 Tahun 2019 merupakan sebuah realita yang harus dihadapi. Fenomena pernikahan dini sekalipun dilarang namun masih kerap terjadi di masyarakat. Mukson (2013), mengartikan pernikahan dini adalah pernikahan yang terjadi pada usia dibawah ketentuan aturan yang berlaku. Berdasarkan data yang diperoleh dari Pengadilan Agama Kabupaten Madiun, bahwa terjadi kenaikan 100\% kasus pernikahan dini. Jumlah pernikahan dini di Kabupaten Madiun selama masa pandemi COVID-19 mencapai 175 orang/pasangan sepanjang tahun 2020 . Secara umum, kecenderungan pernikahan dini yang terjadi disebabkan oleh berbagai faktor, seperti faktor ekonomi, faktor individu, dan faktor pengetahuan atau pendidikan anak serta orang tua yang masih kurang. Masa pandemi COVID-19 ini mempengaruhi kondisi ekonomi masyarakat secara menyeluruh. Secara ekonomi, masyarakat mengalami kesulitan dalam hal mencari pangan karena diterapkannya berbagai aturan maupun kebijakan yang harus dilaksanakan. Faktor individu yang terjadi lebih banyak karena pengaruh lingkungan, baik lingkungan di masyarakat dan/atau lingkungan teman sebaya. Faktor pengetahuan atau tingkat pendidikan juga memberikan pengaruh yang cukup besar bagi subjek. Tingkat pendidikan yang rendah akan mempengaruhi pola berpikir individu. Hasil penelitian Triningtyas, D.A., \& Muhayati, S. (2017) mengungkapkan bahwa secara keseluruhan pernikahan dini yang dilakukan oleh pasangan muda mempunyai dampak secara psikologis dan belum siap dalam menghadapi peran yang baru dalam berumah tangga. Merujuk pada hasil wawancara yang dilakukan oleh peneliti diperoleh gambaran bahwa pernikahan di usia dini yang terjadi disebabkan oleh married by accident.

Married by accident merupakan pernikahan yang harus dilakukan karena telah terjadi kecelakaan (accident). Accident adalah sebuah kejadian yang mengejutkan atau kecelakaan, dimana kehamilan yang terjadi pada umumnya tidak direncanakan oleh salah seorang pasangan atau kedua pasangan yang mengalaminya. Kehamilan yang terjadi sebelum menikah secara sah menurut norma dan agama, bukanlah sesuatu yang diharapkan sehingga memerlukan solusi. Dalam hal ini, alternatif penyelesaian permasalahan yang diambil oleh keluarga dan pasangan hanyalah melalui sebuah pernikahan.Orang tua harus menikahkan puterinya, dimana kondisi ini terjadi dengan suatu penyebab yakni pihak perempuan telah lebih dulu mengalami kehamilan. Untuk menutupi aib yang telah terjadi, maka orang tua atau pihak keluarga perlu melakukan hal tersebut. Ketidaksiapan pasangan dalam menghadapi permasalahan yang terjadi akibat accident, dapat menimbulkan berbagai gejolak seperti merasa malu 
baik terhadap diri sendiri, keluarga dan juga masyarakat. Hal lain yang dialami oleh subjek atau pasangan ini adalah berupa penolakan atas kehamilan yang sudah terjadi sebelum menikah. Akibat dari penolakan ini dapat menimbulkan trauma secara psikologis pada diri subjek atau pasangan. Membahas married by accident yang telah terjadi, berkaitan erat perilaku seksua yang terjadil dengan melibatkan dua orang yang memiliki hubungan dekat (berpacaran atau saling mencintai satu sama lain). Hubungan seksual ini rentan terjadi diantara mereka yang telah meningkat remaja menuju dewasa.Bentuk perilaku seksual ini, umumnya diawali saat mereka (pasangan) mulai berpacaran, berpegangan tangan, berciuman, dan petting(meraba atau merangsang bagianbagian tubuh yang sensitif), dan kemudian berlanjut pada hubungan seksual. Hubungan seksual tidak akan terjadi selama masa berpacaran apabila masing-masing pasangan ini memiliki kontrol diri yang kuat. Hal ini selaras dengan hasil penelitian Dewi (2014), yang mengungkapkan bahwa apabila kontrol diri rendah maka perilaku seksualnya akan tinggi, demikian sebaliknya. Kontrol diri individu yang baik akan mampu mengendalikan emosi serta dorongan-dorongan yang muncul dalam dirinya, termasuk dorongan dalam hubungan seksualnya.

\section{SIMPULAN}

Berdasarkan data yang diperoleh, jumlah pernikahan dini selama masa pandemi COVID-19 mengalami kenaikan hingga mencapai 175 orang/pasangan sepanjang tahun 2020. Hasil penelitian menunjukkan bahwa fenomena pernikahan dini yang terjadi selama masa pandemi COVID-19 disebabkan karena married by accident. Membahas married by accident yang telah terjadi, berkaitan erat dengan perilaku seksual. Hubungan seksual ini rentan terjadi diantara mereka yang telah meningkat remaja menuju dewasa. Hubungan seksual tidak akan terjadi selama masa berpacaran apabila masingmasing pasangan ini memiliki kontrol diri yang baik atau kuat

\section{DAFTAR PUSTAKA}

Apriliani, F.T., Nurwati, N. (2020). Pengaruh

Perkawinan Muda terhadap Ketahanan

Keluarga. Prosiding Penelitian \&

Pengabdian kepada Masyarakat, Vol. 7, No.

1, 90-99 Cucinotta, D., \& Vanelli, M. (2020). WHO declares COVID-19 a pandemic. Acta Bio-Medica: Atenei Parmensis, 91 (1), 157-160Dewi, A.K. (2014). Hubungan Kontrol Diri dengan Perilaku Seksual Pranikah Pada MahasiswaUniversitas Negeri Semarang. Developmental and Clinical Psychology, DCP 3 (1) (2014)Mahase, E. (2020). COVID -19: WHO declares pandemic because of "alarming levels" of spread, severity and inaction. BMJ (Clinical Research Ed.), 368 (m1036), 1 Moleong, L.J. (2011). Metode Penelitian Kualitatif. Bandung: Remaja RosdakaryaMukson. (2013). Tradisi Perkawinan Usia Dini di Desa Tegaldowo. Jurnal Bimas Islam, Vol. 6, No. 1, 2013, 1450ktavia, E.R., Agustin, F.R., Magai, N.M., Widyawati, S.A., Cahyati, W.H. (2018). Pengetahuan Resiko Pernikahan Dini Pada Remaja Umur 13-19 Tahun. Higeia 2 (2) (2018), 239-248Sohrabi, C., Alsafi, Z., 
Neil, N.O., Khan, M., Kerwan, A., Al-jabir, A., Losifidis, C., \& Agha, R. (2020). World Health Organization declares global emergency: A review of the 2019 novel coronavirus (COVID-19).International Journal of Surgery, 76, 71-76Sugiyono. (2019). Metode Penelitian Kuantitif Kualitatif dan R\&D. Bandung: Alfabeta Undang-Undang Republik Indonesia Nomor 1 Tahun 1974 tentang PerkawinanUndangUndang Republik Indonesia Nomor 16 Tahun 2019 tentang Perubahan atas Undang-Undang Nomor 1 Tahun 1974 tentang PerkawinanWahyono, P., Husamah, H., Budi, A.S. (2020). Guru professional di masa pandemic COVID-19: Review implementasi, tantangan, dan solusi pembelajaran daring. Jurnal Pendidikan Profesi Guru, Vol. 1 (No. 1), 51-65 Watkins, J. (2020). Preventing a COVID-19 pandemic. The BMJ, 368 (February), 1-2Triningtyas, D.A., \& Muhayati, S. (2017). Konseling Pranikah: Sebuah Upaya Mereduksi Budaya Pernikahan Dini di Kecamatan Pulung Kabupaten Ponorogo. JKI (Jurnal Konseling Indonesia), 3 (1), 28-32. 